\title{
PRELIMINARY PHYTOCHEMICAL SCREENING AND IN VITRO ANTI-MICROBIAL ACTIVITY OF ETHANOLIC EXTRACTS OF SEEDS OF PUNICA GRANATUM AGAINST STANDARD PATHOGENIC STRAINS
}

\author{
ADITYA JYOTI BORA*, BISWAJIT DASH, SUJATA PAUL, BIKASH GUPTA \\ Girijananda Chowdhury Institute of Pharmaceutical Science, Azara, Guwahati, Assam 781017 \\ Email: adijbora99@gmail.com
}

Received: 24 Apr 2018, Revised and Accepted: 10 Jun 2018

\begin{abstract}
Objective: To estimate the anti-microbial activity of ethanolic extract of Punica granatum seeds (family-Punicaceae) in association with phytochemical analysis.

Methods: The ethanolic extract of the seeds of Punica granatum was prepared and investigate for phytochemical constituents using standard methods. Antimicrobial activities of ethanolic extract were carried out against one Gram positive bacteria (Staphylococcus aureus) and one Gram negative bacteria (Escherichia coli). The anti-fungal activity of the plant extract was evaluated on Candida albicans. The testing was done by the disc diffusion method. A zone of inhibition of ethanolic extract was compared with that of standard Tetracycline for anti-bacterial activities and Fluconazole for anti-fungal activity.
\end{abstract}

Results: The result of this study showed a good antibacterial effect of pomegranate juice against both Gram negative and Gram positive bacteria. The antimicrobial activity of the fruit may be due to its high content of polyphenols which causes phenolic toxicity by interfering with the sulfhydryl group of the bacterial proteins and high content of tannins which interferes with bacterial membrane stability.

Conclusion: The present study concluded that ethanolic extract of the seeds of Punica granatum contains the high existence of phytochemicals. The ethanolic extract of the plant was found to possess promising antimicrobial activity when compared with the standards.

Keywords: Punica granatum, Anti-microbial, Agar disc diffusion method, Zone of Inhibition

(C) 2018 The Authors. Published by Innovare Academic Sciences Pvt Ltd. This is an open access article under the CC BY license (http://creativecommons.org/licenses/by/4.0/)

DOI: http://dx.doi.org/10.22159/ijcpr.2018v10i4.28464

\section{INTRODUCTION}

Antimicrobial resistance (AMR) within a wide range of infectious agents is a growing public health threat of broad concern to countries and multiple sectors. Increasingly, governments around the world are beginning to pay attention to a problem so serious that it threatens the achievements of modern medicine. Antimicrobial resistance (AMR) threatens the effective prevention and treatment of an ever-increasing range of infections caused by bacteria, parasites, viruses and fungi [1]. Plants are rich in a wide variety of secondary metabolites, such as tannins, terpenoids, alkaloids, and flavonoids, which have been found in vitro to have antimicrobial properties. The use of and search for drugs and dietary supplements derived from plants have accelerated in recent years [2].

\section{Herbal drug food-A perspective}

The growing acceptance of the role of diet in disease prevention and treatment has motivated product development and moved organizations, companies involved in formulating foods of health benefit into new areas of understanding like health risk, risk/benefit analysis, evaluation of efficacy and toxicity, as well as health regulations. The impact of this motivation is such that even non-food companies have started venturing into the functional food/nutraceutical area [3] Punica granatum which belongs to the family of Punicaceae, is commonly known as a pomegranate is a deciduous spreading shrub or small tree and has thorns with it. This plant is found all over India [6] has been used extensively as a traditional medicine in many countries [6] for the treatment of dysentery, diarrhoea, helminthiasis, acidosis, haemorrhage and respiratory pathologies. It is one of the most common and delicious fruist that has been used as a desert and condiment in several dishes from the early times [4]. The juice serves as an energy drink in several sports and other physical activities. It is considered as a 'Royal Fruit' due to its high content of minerals, vitamins, electrolytes and many other phytoconstituents that have been prove to shonw its pharmacological action. The anti-microbial activity of the fruit comes from its high content of phenolic compounds like gallic acid, protocatechuic acid, chlorogenic acid, caffeic acid, ferulic acid, $o$-and $p$-coumaric acids, catechin, phloridzin and quercetin [5].

In this present study, the antimicrobial activity of two viable strains of bacteria includes Staphylococcus aureus (S. aureus), Escherichia coli (E. coli) and one fungal strain Candida albicans (C. albicans)

The healthcare costs for fighting Methicillin-Resistant Staphylococcus aureus MRSA infections is in the billions of dollars per year worldwide. These particular strains have a growing diversity in the structure of the genetic element that confers resistance [6]

Escherichia coli can act as reservoirs of resistance genes in the human gut. These resistant genes might be rapidly transferred to other pathogenic organisms $[7,8]$. Fecal E. coli is regarded as a useful indicator of the spread of acquired antibiotic resistance genes in the community $[9,10]$.

Resistance of C. albicans involves mutations in 14C-lanosterol demethylase, targeted by fluconazole (A famous Anti Fungal Drug) and brings out up-regulate efflux genes that probably efflux the Anti-fungal [11].

A sufficient quantity of phenolic compounds, including phenolic acid flavonoid and flavonol compounds have been reported in the peel, juice and seeds of the fruit from previous studies which is corely responsible for its potent anti-oxidant and anti-microbial activity. The peel extract showed a high content of these phenolic compounds with respect to juice and seeds [12].

The potent Anti-microbial activity was also reported in the fruit due to its high tannin content up to a maximum of $2.03 \%$ depending on the varieties [13].

\section{MATERIALS AND METHODS}

Plant materials

Fresh fruits of pomegranate were collected from the Local fruit market of Paltan bazaar, Guwahati, Assam. Plant materials were 
identified by Dr IC Barua, Principal Scientist, Assam Agriculture University, Jorhat, Assam. A voucher specimen (Acc-5201, Dated: 2/5/2018) was kept in, Assam Agriculture University, Department Of Agronomy for future reference and fruits were then subjected to wash in running tap water to remove dirt and insects from the surface. The seeds were separated out from the fruit arils and dried in a conventional dryer at $45^{\circ} \mathrm{C}$ for $5 \mathrm{~d}$ until the complete moisture was evaporated off. The dried seeds were then crushed into a coarse powder using a manual mortar and pestle. The powdered about 50 grams of the powdered drug was then defatted using $500 \mathrm{ml}$ petroleum ether by soxhlet extraction for $72 \mathrm{~h}$. The extract was filtered and the filtrate was kept in a cool place at 4C. The defatted mark was collected and again extracted using absolute ethanol by a cold marceration technique for a period of 7 $\mathrm{d}$ with occasional shaking. The extract was filtered using Whatman No.1 filter paper and collected in a Petridis. The organic solvent was evaporated by heating. The dried extract was then undertaken for serial dilution technique to obtain different concentrations of $25 \mathrm{mg} / \mathrm{ml}, 50 \mathrm{mg} / \mathrm{ml}, 100 \mathrm{mg} / \mathrm{ml}, 150 \mathrm{mg} / \mathrm{ml}$ and $200 \mathrm{mg} / \mathrm{ml}$ respectively. The prepared concentrations were then stored in a cool place at $4^{0} \mathrm{C}[14,15]$.

\section{Test culture}

Bacterial strains of S. aureus and E. coli and fungal strain C. albicans were availed from the microbiology laboratory of Girijananda Chowdhury Institute of Pharmaceutical science Guwahati, Assam. Required amount of nutrient agar media was prepared and the standard pathogenic strain suspension was spread about $150 \mu \mathrm{l}$ spread over $20 \mathrm{~mm}$ thick Mueller Hinton Agar (MHA) with an Lshaped glass rod and left for 5 min to dry.

\section{Antimicrobial activity of $P$. granatum seeds extract}

The effects of $P$. granatum peel extracts on bacterial growth were measured by in vitro agar well diffusion assay according to the technique described [16] with slight modification. Twelve wells with $0.6 \mathrm{~mm}$ diameter were made on the solidified media. Each well was filled with $50 \mu \mathrm{l}$ of each extract of Ethanol and petroleum ether of different concentration of $25,50,100,150$ and $200 \mathrm{mg} / \mathrm{ml}$.

The other two empty wells were filled with $50 \mu \mathrm{l}$ of Tetracycline (30 $\mu \mathrm{g} / \mathrm{ml})$ and fluconazole $50 \mu \mathrm{l}(20 \mu \mathrm{g} / \mathrm{ml})$ as a positive control and 50 $\mu \mathrm{l}$ of absolute ethanol as a negative control. All plates were then incubated at $30^{\circ} \mathrm{C}$ for $24 \mathrm{~h}$ and were done. Measured with a ruler in millimeter $(\mathrm{mm})$ the zones around the wells were will record as inhibition zone for extracts.

\section{Phytochemical assessment of extract}

All the extracts were qualitatively analyzed for various secondary metabolites. Carbohydrate presence was confirmed by Molish's test, glycoside was confirmed by Borntrager's test (Evan, 1997), alkaloids was evaluated by Mayer's test, saponins were analyzed by Froth's Test (Kokate, 1999), tannins were studied by gelatin test (Mace, 1963), flavonoid was investigated by lead acetate test, amino acid was assessed by Ninhydrin's test (Yasuma and Ichikawa, 1953), Anthraquinones was confirmed by Borntrager's test, steroids by Salkowski's test, phenols by ferric chloride test, lipids were determined by Sudan Red Test and presence of terpenoids was determined by reddish precipitate from chloroform and sulfuric acid interaction in the extract $[17,18]$.

\section{RESULTS}

The anti-microbial activity against both the bacterial strains $S$. aureus (Positive) and E. coli (negative), as well as fungal strain C. albicans, was evaluated by measuring the zone of inhibition using both petroleum ether as well as ethanol extract. Maximum zone of inhibition was obtained from ethanolic seeds extract against $S$. aureus at a concentration of $200 \mathrm{mg} / \mathrm{ml}$ compared to positive control followed by E. coli and then C. albicans as shown in table 1 . The zone of inhibitions showed by petroleum ether was comparatively less then as showed by ethanol.

The zone of inhibition shown by the dose $200 \mathrm{mg} / \mathrm{ml}$ of ethanolic extract was comparable with the standard drug tetracycline showing the potency of our test drug able to use as anti-microbial.

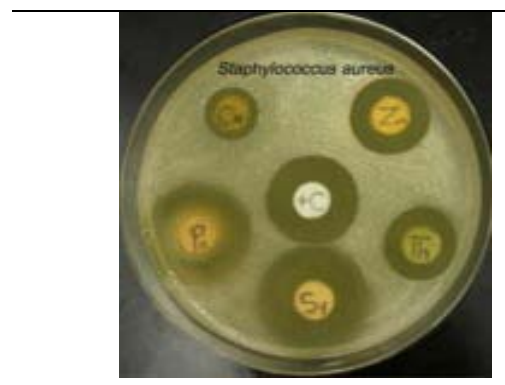

Fig. 1: Z0I for Streptococcus aureus

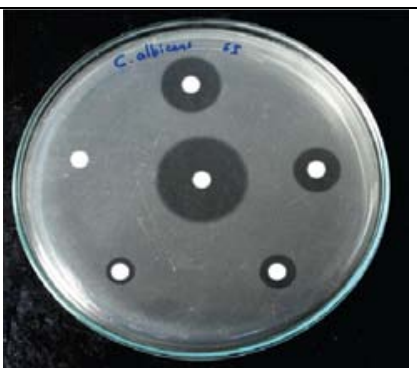

Fig. 2: ZOI for Candida albicans

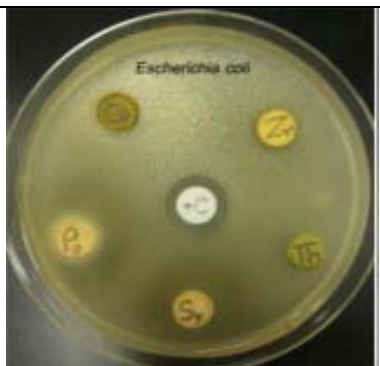

Fig. 3: ZOI for Escherichia col

Table 1: the Anti-microbial activity of Punica granatum determining Zone of Inhibition (ZOI) of ethanolic and petroleum ether seed extract against gram positive bacteria (S. aureus), gram negative bacteria (E. coli) and fungal strain (C. albicans) at various doses

\begin{tabular}{|c|c|c|c|c|c|}
\hline $\begin{array}{l}\text { Extract dose In } \\
\mathrm{mg} / \mathrm{ml}\end{array}$ & $\begin{array}{l}\text { Test } \\
\text { organism }\end{array}$ & $\begin{array}{l}\text { Ethanolic extract } \\
\text { ZOI }\end{array}$ & $\begin{array}{l}\text { Petroleum ether } \\
\text { extract ZOI }\end{array}$ & Positive control & $\begin{array}{l}\text { Negative control (absolute } \\
\text { ethanol) ZOI }\end{array}$ \\
\hline \multirow[t]{2}{*}{25} & S. aureus & & & (Tetracycline $30 \mu \mathrm{g} / \mathrm{ml}$ ) ZOI & \\
\hline & & $22 \mathrm{~mm}$ & $16 \mathrm{~mm}$ & $48 \mathrm{~mm}$ & $5 \mathrm{~mm}$ \\
\hline 50 & & $28 \mathrm{~mm}$ & $23 \mathrm{~mm}$ & $48 \mathrm{~mm}$ & $5 \mathrm{~mm}$ \\
\hline 100 & & $35.3 \mathrm{~mm}$ & $25 \mathrm{~mm}$ & $48 \mathrm{~mm}$ & $5 \mathrm{~mm}$ \\
\hline 150 & & $38 \mathrm{~mm}$ & $27 \mathrm{~mm}$ & $48 \mathrm{~mm}$ & $5 \mathrm{~mm}$ \\
\hline 200 & & $42 \mathrm{~mm}$ & $34 \mathrm{~mm}$ & $48 \mathrm{~mm}$ & $5 \mathrm{~mm}$ \\
\hline 25 & & $20 \mathrm{~mm}$ & $15.3 \mathrm{~mm}$ & $48.5 \mathrm{~mm}$ & $5 \mathrm{~mm}$ \\
\hline 50 & E. coli & $27.6 \mathrm{~mm}$ & $22 \mathrm{~mm}$ & $48 \mathrm{~mm}$ & $5 \mathrm{~mm}$ \\
\hline 100 & & $35 \mathrm{~mm}$ & $24 \mathrm{~mm}$ & $48.8 \mathrm{~mm}$ & $4.5 \mathrm{~mm}$ \\
\hline 150 & & $38 \mathrm{~mm}$ & $26.5 \mathrm{~mm}$ & $47.8 \mathrm{~mm}$ & $5 \mathrm{~mm}$ \\
\hline 200 & & $42 \mathrm{~mm}$ & $27 \mathrm{~mm}$ & $48 \mathrm{~mm}$ & $5 \mathrm{~mm}$ \\
\hline \multirow[t]{2}{*}{25} & C. albicans & & & (Fluconazole $20 \mu \mathrm{g} / \mathrm{ml}$ ) ZOI & \\
\hline & & $21 \mathrm{~mm}$ & $7 \mathrm{~mm}$ & $28 \mathrm{~mm}$ & $5 \mathrm{~mm}$ \\
\hline 50 & & $22 \mathrm{~mm}$ & $16.6 \mathrm{~mm}$ & $28 \mathrm{~mm}$ & $5 \mathrm{~mm}$ \\
\hline 100 & & $26 \mathrm{~mm}$ & $18 \mathrm{~mm}$ & $29 \mathrm{~mm}$ & $4.2 \mathrm{~mm}$ \\
\hline 150 & & $32 \mathrm{~mm}$ & $21 \mathrm{~mm}$ & $28.6 \mathrm{~mm}$ & $4 \mathrm{~mm}$ \\
\hline 200 & & $35 \mathrm{~mm}$ & $25 \mathrm{~mm}$ & $27 \mathrm{~mm}$ & $4 \mathrm{~mm}$ \\
\hline
\end{tabular}



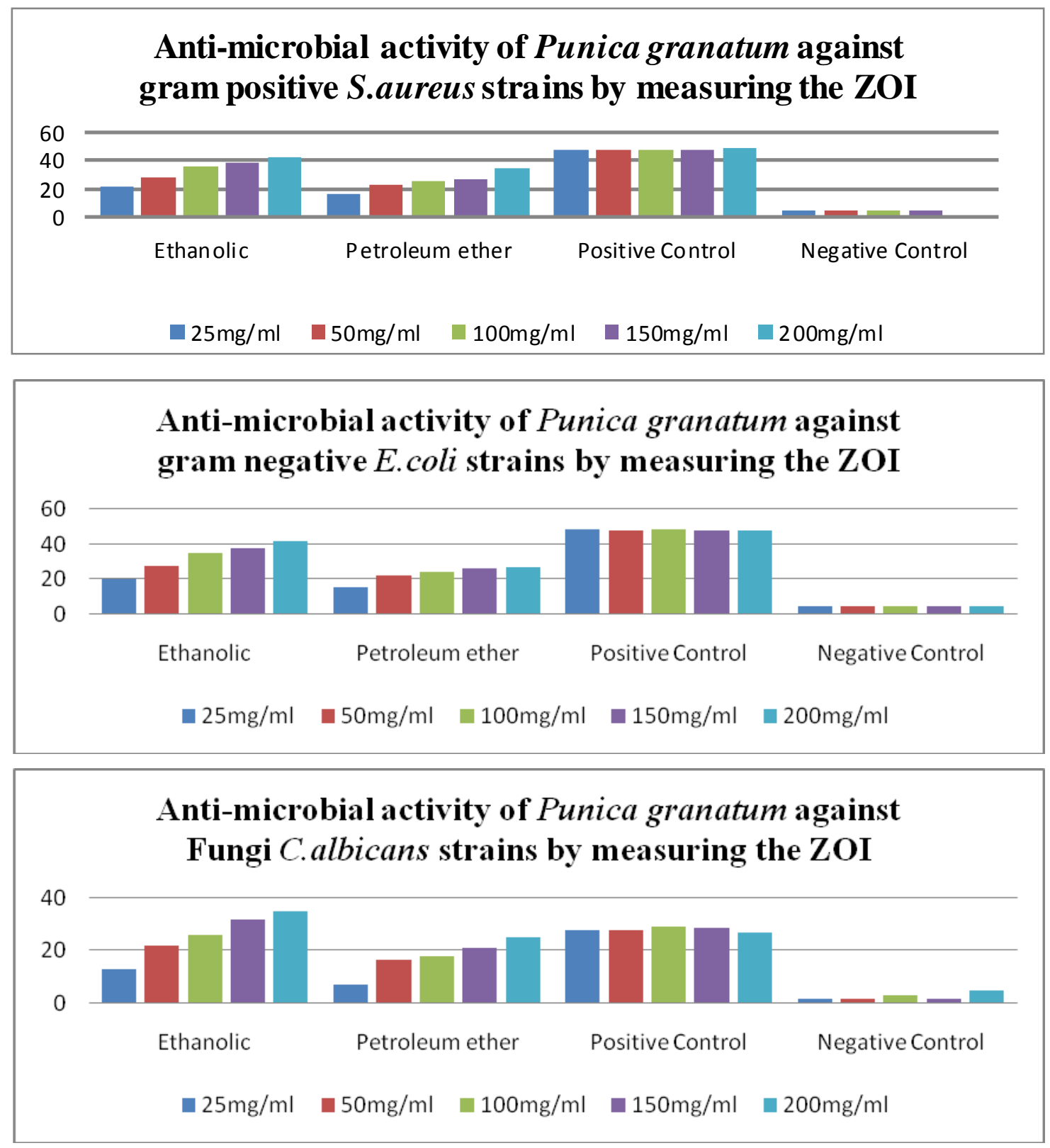

Table 2: Results for the photochemical screening of ethanolic and petroleum ether extract of Punica granatum seeds

\begin{tabular}{lll}
\hline Chemical Groups & Ethanolic extract & Petroleum ether extract \\
\hline Alkaloids & + & + \\
Saponins & + & + \\
Terpenoids & + & + \\
Anthraquinones & + & + \\
Glycosides & - & - \\
Tannins & + & - \\
Flavonoids & + & + \\
Carbohydrates & + & + \\
Phenols & + & + \\
Steroids & + & - \\
Amino Acid & + & + \\
Lipids & + & \\
\hline
\end{tabular}

\section{DISCUSSION}

With the pace of advancement in science and technology, there has been a spectacular public health success with regard to the control of various microbial infections. However, microbial pathogens are still responsible for more than 14 million human deaths per annum. Antimicrobial resistant-microbes are found in people, animals, food and the environment (in water, soil and air). They can spread between people and animals, including from food of animal origin, and from person to person. Poor infection control, inadequate 
sanitary conditions and inappropriate food-handling encourage the spread of antimicrobial resistance.

From the data given above, it was found that the Punica granatum seed extract was active against both Gram positive and Gram negative bacterial strains as well it also showed some bacteriostatic effect on the pathogenic fungal strain. The ethanolic extract showed more potent activity than petroleum ether extract at the dose of 200 $\mathrm{mg} / \mathrm{ml}$. This dose was referring to the standard antibiotic dose of tetracycline which showed a zone of inhibition of $48 \mathrm{~mm}$ for both the positive and negative strains of bacteria. The zone of inhibition of test drug at its maximum dose was $42 \mathrm{~mm}$ for both the strains. The standard drug fluconazole showed a bactericidal effect at it given dose showing zone of inhibition of $28 \mathrm{~mm}$ which was acceptable for the ethanolic extract of our test drug at its maximum dose $200 \mathrm{mg} / \mathrm{ml}$ showing a zone of inhibition of $21 \mathrm{~mm}$. However, the petroleum ether extract did not showed a satisfactory result in case of inhibiting the growth of fungal strain. The highest dose of Petroleum ether extract, however, inhibited the growth of fungi although slight possibilities are there for fungicidal action.

The phytochemical screening test for both the seed extract gave positive results for alkaloids, tannins, phenols, carbohydrates, lipids, anthraquinones, steroids, saponins however the ethanolic extract also showed positive results for flavonoids and amino acids which were absent in petroleum ether extract.

The $P$. granantum seeds are considered to be a rich source of polyphenolic compounds like gallotannins, ellagic acid, gallagic acid, punicalins, punicalagin and. The antibacterial effect may return to phenolic compounds as well as tannins which could be increased with the presence of organic acids [19]

In a study from Sivan et al. Antibacterial activity of phenolic compounds followed the sequence phenolic acids>catechins> proanthocyanins [20].

\section{CONCLUSION}

On the basis of data obtained from the study, it can be concluded that the $P$. granatum seed extract has a beneficial effect against the pathogenic microbes. The ethanolic seed extract showed a sufficient inhibitory effect against all the three pathogens in a dose-dependent manner. The petroleum ether extract also slowed down the growth of the pathogens in a dose-dependent manner however the activity was far lesser than ethanolic extract. Probably due to the absence of flavonoidal compounds. The inhibitory effect of phenolic compounds in the extract could be explained by adsorption to cell membranes, interact with enzymes, substrate and metal ion deprivation [21]. These results confirmed the antibacterial potential of pomegranate and its use in traditional medicine [22].

Hence the seed extract of Punica granatum could be used as an alternative or adjunct therapy with other broad-spectrum antibiotics for the treatment of infectious diseases in the coming year, although further studies are required in this field to toss light on the mechanism and component behind the antimicrobial activity of Punica Granatum.

\section{AUTHORS CONTRIBUTIONS}

All the author have contributed equally

\section{CONFLICT OF INTERESTS}

The Author declared there is no conflict of interest

\section{REFERENCES}

1. Antimicrobial resistance a global report on surveillance WHO; 2014. p. 1-231.

2. Marjorie Murphy Cowan Plant Products as Antimicrobial Agents. Clin Microbiol Rev 1999;12:564-82.
3. Haefner B. Drugs from the deep: marine natural products as drug candidates. Drug Discovery Today 2003;8:536-44.

4. Voravuthikunchai SP, Sririrak T, Limsuwan S, Supawita T, lida T, Honda T. Inhibitory effects of active compounds from Punica granatum pericarp on verocytotoxin production by enterohemorrhagic Escherichia coli 0157:H7.J Health Sci 2005;51:590-6.

5. Ender Poyrazoglu, Vural Gokmen, Nevzat Artık, Organic acids and phenolic compounds in pomegranates (Punica granatum L.) grown in turkey. 2002;15:567-75.

6. WC Reygaert. Antimicrobial resistance mechanisms of Staphylococcus aureus Microbial pathogens and strategies for combating them: science, technology and education; Formatex; 2013.

7. Salyers AA, Gupta A, Wang Y. Human intestinal bacteria as reservoirs for antibiotic resistance genes. Trends Microbiol 2004;12:412-6.

8. Blake DP, Hillman K, Fenlon DR, Low JC. Transfer of antibiotic resistance between commensal and pathogenic members of the enterobacteriaceae under ileal conditions. J Appl Microbiol 2003;95:428-36.

9. Lester SC, Del Pilar PM, Wang F, Perez Schael I, Jiang H, O’Brien TF. The carriage of Escherichia coli resistant to antimicrobial agents by healthy children in Boston, in Caracas, Venezuela, and in Qin Pu China. N Engl J Med 1990;323:285-9.

10. Nys S, Okeke IN, Kariuki S, Dinant GJ, Driessen C, Stobberingh EE. Antibiotic resistance of faecal escherichia coli from healthy volunteers from eight developing countries. J Antimicrob Chemother 2004;54:952-5.

11. Robert A. Akins an update on antifungal targets and mechanisms of resistance in Candida albicans. Medical Mycol J 2005;43:285-318.

12. Zahra Derakhshan, Margherita Ferrante, Marzieh Tadi, Farnoosh Ansari, Ali Heydari Motahreh, Sadat Hosseini Gea, et al. Antioxidant activity and total phenolic content of ethanolic extract of pomegranate peels, juice and seeds. Food Chem Toxicol 2018;114:108-11.

13. Mannan Hajimahmoodi, Ghazaleh Moghaddam, Ali Mohammad Ranjbar, Hossein Khazani, Naficeh Sadeghi, Mohammad Reza Oveisi, et al. Total phenolic flavonoids tannin content and antioxidant power of some iranian pomegranate flower cultivars (Punica granatum L.). Am J Plant Sci 2013;4:1815-20.

14. Machado TB, Leal CR, Amerl ACF, Santos KRN, Silva MG, Kuster RM. Antimicrobial ellagitannin of Punica granatum fruits. J Brazilian Chem Soc 2002;13:606-10.

15. Silva M, Higino J, Pereira J, Siqueira Jonior J, Pereira M. Antibiotic activity of the extract of Punica granatum Linn over bovine strains of staphylococcus aureus. Rev Bras Farmacogn 2008;18:209-12.

16. Patel R, Patel A, Vaghasiya D, Nagee A. Antimicrobial evaluation of hibiscus rosa-sinensis plant extracts against some pathogenic bacteria. Bull Environ Sci Res 2012;1:14-7.

17. Khan NH, Lee AZY, Goo CZT, Ooi WY. Phytochemical investigation of Punica granatum seeds. Madridge J Pharm Res 2017;1:22-6.

18. Sajjad Ali B, Haq A, Hayat A. Antibacterial activity of Punica granatum peel extract. Mycopath 2011;13:105-11.

19. Al-Zoreky N. Antimicrobial activity of pomegranate (Punica granatum L.) fruit peels. Int J Food Microbiol 2009;134:244-8.

20. M Silvan, E Mingo, M Hidalgo, S Pascual-Teresa, AV Carrascosa AJ Martinez-Rodriguez. Antibacterial activity of a grape seed extract and its fractions against Campylobacter spp. Food Controlled 2013;29:25-31.

21. Scalbert A. Antimicrobial properties of tannins. Phytochemistry 1991;30:3875-83.

22. Rauha JP, Remes S, Heinonen M, Hopia A, Kahkonen M, Kujala $\mathrm{T}$, et al. Antimicrobial effects of Finnish plant extracts containing flavonoids and other phenolic compounds. Int J Food Microbiol 2000;56:3-12. 